\title{
生物物理 と高分子
}

岡小 小 $^{*}$

\section{生物物理亡は}

最近わが国でも生物物理に対する関心が急激に深まりつつあり，昨年 12 月には日本生物物理学会が創 立され会員数も2,000 に達しょうとしている。生命現象の解明は自然科学に叔ける最重要課題の一つであ り, 生物物理振興の気運は世界的動向となっている。生物物理 (Biophysics) とはどんな学問かというこ とであるが，一口でい党ば，生命現象を物理的方法によって研究する分野とい壳よう。生命現象を化学的 方法によって研究する分野を生物化学そいらから，生物物理は生物化学々併立するもののように考穴られ る。実際過去においてはとういう時代もあった。しかし時代とともに学問は進歩し内容は変わっていくも のであり, 現在の生物物理のある分野は化学的色彩が濃く, 生物化学々の境界ははっきりしない。これは 物理学自身が発展したためである。過去に执いては物理学は化学々併立するすのであった。物理学は自然 現象の中で物理的現象を, 化学は化学的現像を扱うことになっていた。ところが量子力学や統計力学の発 達により，化学的現象 (分子構造・反応速度など) も原理的には物理学の範疇に属することが明らかになっ た。さらに物理学は物質の原子的, 分子的構造に基いて物質の物理的性質を説明することに成功し, これ は物性論と呼ばれている。生物物理に特ける“物理”は以前は古典物理であったのが，現在では物性論 を主体とする物理に変わってきたために，生物物理も物性論的，化学的色彩の濃い分野が主体となるに至 ったわケである。

このような生物物理の諸問題を構造の点から大別すると, submolecular レベルでの問題, 分子レベル での問題, 高分子レベルでの問題, 細胞レベルでの問題などになる。また生物物理の諸問題を生物体の機 能の点から大別すると，代謝・感覚・運動・増殖・遺伝などになる。

生物物理には以上と違う面も学る。すおわ生物体の機能を分子的機構から離れて抽象し，モデル化し て理解しようとするゆき方である。ここで取り上げられる問題としては生物体における調節作用や脸の働 きがあり, 情報理論, サイバネティックスや自動制御工学の知識など数学的方法が要求される。

過去に拈いては生物物理といらと医学や生物学の研究に打ける物理的測定技術の応用ないしは物理的手 段の生物体に及ぼす影響を意味したこともあったが，現在の生物物理は生物学一般の方法と物理的, 化学 的，数学的方法とを用いて生命現象の基本的理解を目指している。

\section{高分子からみて}

生物物理の中で高分子の関係する問題はきわめて多い。まず生物体を構成する高分子として最も重要な

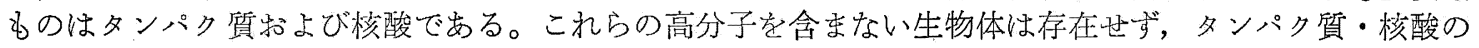
関係する生命現象はきわめて多い。それで生物体から種々のタンパク質や核酸を抽出してその構造や物性 を研符することがすず行なわれる。たと兄ばX線回折法や赤外線，紫外線吸収スペクトルによるタンパク 質・㤥酸の構造研究や，溶液の諸性質 (粘性・光散乱・複屈折・旋光性など) からこれら生体高分子の形・ 大きさ・分子量などを決定することが行なわれた。

生体高分子の構造・物性に関する知識に基いて，これら生体高分子が生命現象に拈いて演ずる役割を物 理的に明らかにすることが次の問題になる。具体的な例をいくつかあげれば，筋収縮に叔けるアクチン・ ミオシンの役割, 神経伝導に拈ける生体膜の役割, 血液の凝固におけるフイブリノーゲンの役割, 呼吸に おけるへモグロビンの役割, 酵素作用の物理的機構, 光合成, タンパク質, 核酸の生合成, ウイルスの増

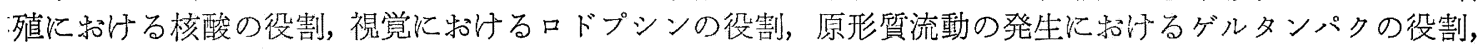
遺伝に和ける DNA 核酸の役割など。これら生命現象には高分子のほが場合によっては，ATP のよう な低分子や， $\mathrm{Na}^{+}, \mathrm{K}^{+}$のようなイオンや，さらに電子や光子なども関係する。X 線や $\gamma$ 線などの㸡射線 は生物体に種々の有害な影響を及ぼし，場合によっては笑变異などの遺伝的影響をも与えるが，これも タンパク質やDNA 核酸に及汭す二次電子の作用がもとになる。微量な線量で甚大な生物学的影響の現わ れるのは細胞がきわめて高度の秩序を有するためと考光られる。

\footnotetext{
* 都立大学理学部教授・理博
} 